\title{
Ampelopsin suppresses TNF- $\alpha$-induced migration and invasion of U2OS osteosarcoma cells
}

\author{
CHANGYING LIU ${ }^{1}$, PENGFEI ZHAO ${ }^{2}$, YUBAO YANG ${ }^{1}$, XIAODONG XU $^{1}$, LIANG WANG $^{1}$ and BO $\mathrm{LI}^{3}$ \\ ${ }^{1}$ Department of Osteology, People's Hospital of Linyi City, Linyi, Shandong 276000; \\ ${ }^{2}$ Department of Osteology, People's Hospital of Yinan County, Linyi, Shandong 276003; \\ ${ }^{3}$ Department of Cardiology, Central Hospital of Zibo, Zibo, Shandong 255036, P.R. China
}

Received May 19, 2015; Accepted February 16, 2016

DOI: $10.3892 / \mathrm{mmr} .2016 .5124$

\begin{abstract}
Ampelopsin has been suggested as a novel anticancer agent, however, there is no evidence regarding its direct effect on the migration and invasion of osteosarcoma cells. The aims of the present study were to investigate the influence of ampelopsin on the migration and invasion of osteosarcoma cells and to clarify the underlying mechanisms. Scratch wound healing and Transwell assays were used to measure the migratory and invasive activities of the cells, respectively. The protein and RNA levels of matrix metalloproteinase-2 (MMP-2) were detected with western blot and RT-qPCR, respectively, following stimulation with tumor necrosis factor- $\alpha(\mathrm{TNF}-\alpha)$ and ampelopsin. The expression levels of phospho- and total-p38MAPK were detected using western blot analysis. Additionally, SB203580, an inhibitor of p38MAPK, was used to investigate the effect of TNF- $\alpha$ and ampelopsin. The results demonstrated that TNF- $\alpha$ upregulated the expression level of MMP-2 and promoted the migration and invasion of osteosarcoma cells. TNF- $\alpha$ also activated the p38MAPK pathway, and SB203580 significantly inhibited the effect of TNF- $\alpha$ on MMP-2 expression. The application of ampelopsin abolished the effects of TNF- $\alpha$ on the activation of the p38MAPK pathway and the expression of MMP-2, and downregulated the migration and invasion of the osteosarcoma cells. These results demonstrated that ampelopsin inhibits the TNF- $\alpha$-induced migration and invasion of osteosarcoma cells, and that the effect of ampelopsin was mediated by p38MAPK/MMP-2 signaling.
\end{abstract}

Correspondence to: $\mathrm{Dr}$ Bo Li, Department of Cardiology, Central Hospital of Zibo, 54 Gong Qing Tuan Xi Road, Zibo, Shandong 255036, P.R. China

E-mail: libosubmit@163.com

Dr Yubao Yang, Department of Osteology, People's Hospital of Linyi City, 27 Jie Fang Road, Linyi, Shandong 276000, P.R. China E-mail: yangyubao9999@sina.com

Key words: osteosarcoma, ampelopsin, TNF- $\alpha$, p38MAPK, MMP-2

\section{Introduction}

Osteosarcoma is one of the most common malignant bone tumors and predominantly occurs in the long bones, including the humerus, ulna, radius, femur, fibula and pelvis, of adolescents and children. Although the mortality rate of osteosarcoma has declined and the survival rate has increased dramatically over the past decade with the improvement of chemotherapy and aggressive surgical techniques (1), the prognosis of patients with metastasis remains poor, with only a $20 \% 5$-year survival rate (2). Thus, it is important to further clarify the underlying molecular signaling mechanisms that regulate osteosarcoma, and to develop effective strategies to control osteosarcoma carcinogenesis and metastasis.

The mechanisms of osteosarcoma metastasis are complex, requiring multiple processes and various physiological changes. Evidence has demonstrated that the degradation of the extracellular matrix $(\mathrm{ECM})$ is a pivotal process in the migration and invasion of osteosarcoma cells. Numerous factors are associated with the process of ECM degradation, such as matrix metalloproteinase-2 (MMP-2), which enables cancer cells to degrade the ECM facilitating the migration and invasion of tumor cells toward the bloodstream. MMP-2 production and activation is induced by various cytokines, of which tumor necrosis factor- $\alpha$ (TNF- $\alpha$ ) is one of the most important mediators $(3,4)$.

Ampelopsin (3,5,7,3'4'5'-hexahydroxyl 2,3 dihydrogen flavonol), one of the most common flavonoids, is derived from the tender stem and leaves of the plant species Ampelopsis grossedentata, which has been widely used in traditional Chinese medicine $(5,6)$. Ampelopsin has been used in the treatment of numerous diseases, including inflammation (5), oxidative stress (5), liver injury (7) and hyperlipidemia (8). Previous studies have investigated the anticancer effect of ampelopsin in prostate (9), ovarian (10) and breast (11) cancer. However, to the best of our knowledge there are no reports of the anticancer activity of ampelopsin on osteosarcoma cells. The present study aimed to investigate whether ampelopsin may exert an effect against osteosarcoma cell migration and invasion.

\section{Materials and methods}

Reagents. Ampelopsin and recombinant human TNF- $\alpha$ were purchased from Sigma-Aldrich (St. Louis, MO, USA). Mouse 
monoclonal MMP-2 and GAPDH antibodies were purchased from Abcam (Cambridge, UK; cat. nos. ab2462 and ab8245, respectively). Rabbit monoclonal total-p38 mitogen activated protein kinase (MAPK) and phospho-p38MAPK were purchased from Cell Signaling Technology, Inc. (Danvers, MA, USA; cat. nos. 8690 and 4511, respectively). SB203580, a selective inhibitor of the p38MAPK signaling pathway, was purchased from Sigma-Aldrich.

Cell culture. U2OS osteosarcoma cells were purchased from the American Type Culture Collection (Manassas, VA, USA). U2OS cells were seeded and maintained at $37^{\circ} \mathrm{C}$ in a humidified atmosphere of $5 \% \mathrm{CO}_{2}$ in Hyclone Dulbecco's modified Eagle's medium (DMEM; GE Healthcare Life Sciences, Logan, UT, USA) supplemented with 10\% Hyclone fetal bovine serum (FBS; GE Healthcare Life Sciences), $100 \mathrm{U} / \mathrm{mlpenicillinand} 100 \mu \mathrm{g} / \mathrm{mlstreptomycin}$ (Sigma-Aldrich).

Western blot analysis. To clarify the effect of TNF- $\alpha$ on the expression of MMP-2, U2OS cells were cultured in 6-well plates, and were randomly divided into 5 groups as follows: Control, physiological saline of equal volume; 1, 10, 50 and $100 \mathrm{ng} / \mathrm{ml} \mathrm{TNF}-\alpha$ for $24 \mathrm{~h}$. Furthermore, U2OS cells were pretreated with ampelopsin $(5,10$ and $50 \mu \mathrm{M})$ for $2 \mathrm{~h}$ prior to $\mathrm{TNF}-\alpha$ treatment $(100 \mathrm{ng} / \mathrm{ml})$ for $24 \mathrm{~h}$, and the relative expression of MMP-2 was determined. To ascertain the effect of TNF- $\alpha$ on the p38MAPK signaling pathway, U2OS cells were cultured and stimulated with TNF- $\alpha(100 \mathrm{ng} / \mathrm{ml})$ for 5 , $15,30,60$ and $120 \mathrm{~min}$. A different set of cells were treated with $50 \mu \mathrm{M}$ ampelopsin for $2 \mathrm{~h}$ prior to TNF- $\alpha$ treatment (100 ng/ml) for 5, 15, 30, 60 and $120 \mathrm{~min}$, and the phosphorylation of p38MAPK was detected using western blot analysis. In addition, SB203580 (10 mmol/l), an inhibitor of the p38 pathway, was used to pre-treat another set of U2OS cells for $2 \mathrm{~h}$ prior to TNF- $\alpha(100 \mathrm{ng} / \mathrm{ml})$ treatment for $24 \mathrm{~h}$.

For detection of the target proteins, ampelopsin, SB203580 or TNF- $\alpha$-treated cancer cells were collected and lysed for $30 \mathrm{~min}$ in a lysis buffer containing phenylmethylsulfonyl fluoride, EDTA, pepstatin and leupeptin as protein inhibitors (Beyotime Institute of Biotechnology, Haimen, China). Lysates were then centrifuged at $21,000 \mathrm{x} \mathrm{g}$ at $4^{\circ} \mathrm{C}$ for $15 \mathrm{~min}$ to remove the insoluble material. The concentrations of the extracted proteins were measured with a bicinchoninic acid protein assay kit (Beyotime Institute of Biotechnology) following the manufacturer's instructions. The protein lysates $(10 \mu \mathrm{g})$ were subjected to $10 \%$ SDS-PAGE according to the concentrations at $90 \mathrm{~V}$. Following electrophoresis, the proteins were electrotransferred to nitrocellulose membranes (EMD Millipore, Billerica, MA, USA) at $200 \mathrm{~mA}$ for $2 \mathrm{~h}$. In order to minimize the non-specific binding, the blots were blocked in $5 \%$ non-fat milk for $2 \mathrm{~h}$ at room temperature. The blots were then incubated with antibodies against MMP-2 (1:1,000), total-p38MAPK $(1: 1,500)$, phospho-p38MAPK $(1: 1,500)$ and GAPDH $(1: 10,000)$ overnight at $4^{\circ} \mathrm{C}$. The blots were washed and exposed to horseradish peroxidase-conjugated goat anti-rabbit and goat anti-mouse secondary antibodies (Beijing Zhongshan Golden Bridge Biotechnology Co., Ltd.; OriGene Technologies, Inc., Rockville, MD, USA; cat. nos. ZDR-5306 and ZDR-5307, respectively) for $2 \mathrm{~h}$, and the levels of the target proteins were detected by the FluorChem HD2 electrochemiluminescence detection system (Alpha Innotech Corporation, Sa Jose, CA, USA) and an enhanced chemiluminescence reagent (EMD Millipore). The quantification of the scanned blots was performed using ImageJ software (imagej. nih.gov/ij/) and the results are expressed as fold change relative to the control. Three independent experiments were duplicated for each reaction.

$R N A$ extraction and reverse transcription-quantitative polymerase chain reaction ( $R T-q P C R)$ analysis. U2OS cells were cultured in 6-well plates, and were randomly divided into 5 groups as follows: Control, physiological saline of equal volume; $1,10,50$ and $100 \mathrm{ng} / \mathrm{ml} \mathrm{TNF}-\alpha$ for $24 \mathrm{~h}$. Another set of cells were pretreated with SB203580 (10 mmol/l) or ampelopsin (5, 10 and $50 \mu \mathrm{M}$ ) for $2 \mathrm{~h}$ prior to TNF- $\alpha$ treatment for $24 \mathrm{~h}$, and the expressions of MMP-2 at the mRNA level were detected. Total RNA was extracted from the U2OS osteosarcoma cells using TRIzol reagent (Invitrogen; Thermo Fisher Scientific, Inc., Carlsbad, CA, USA), and measured using a SmartSpec 3000 UV/Vis spectrophotometer (Bio-Rad Laboratories, Inc., Beijing, China). RT was performed using oligo (dT) primers (Boshang Biology Technology Ltd., Shanghai, China; MMP-2 primers cat. no. H187580; 18s primers cat. no. H179060) and the RevertAid First Strand cDNA Synthesis kit (Fermentas; Thermo Fisher Scientific, Inc., Pittsburgh, PA, USA) at $37^{\circ} \mathrm{C}$ for $1 \mathrm{~h}$ according to the manufacturer's instructions. Briefly, reverse transcription was performed at $37^{\circ} \mathrm{C}$ for 10 min using $1 \mu \mathrm{g}$ RNA, $1 \mu \mathrm{l}$ oligo (dT) primers and $10 \mu \mathrm{l}$ RNase-free water. Mixture was incubated at $70^{\circ} \mathrm{C}$ for $10 \mathrm{~min}$ and $4 \mu \mathrm{l} 5 \mathrm{X}$ reaction buffer, $1 \mu \mathrm{l}$ ribonuclease inhibitor and $2 \mu \mathrm{l} \mathrm{dNTP}$ were added. Following incubation at $37^{\circ} \mathrm{C}$ for $5 \mathrm{~min}, 2 \mu \mathrm{l}$ reverse transcriptase were added to the mixture, and the final $20 \mu \mathrm{l}$ reaction mixture was cultured at $37^{\circ} \mathrm{C}$ for $1 \mathrm{~h}$. The enzymatic activity was inactivated by heating at $65^{\circ} \mathrm{C}$ for $10 \mathrm{~min}$ at the end of the incubation period.

RT-qPCR was subsequently performed with the SYBR Green I kit (Takara Bio, Inc., Otsu, Japan) according to the manufacturer's instructions and analyzed using a LightCycler (Roche Diagnostics, Mannheim, Germany) with 18sRNA as a reference gene. The thermal cycling conditions used for qPCR were as follows: denaturing at $94^{\circ}$ for $30 \mathrm{sec}$, annealing at $58^{\circ} \mathrm{C}$ for $30 \mathrm{sec}$ and extension at $72^{\circ} \mathrm{C}$ for $30 \mathrm{sec}$, a total of 37 cycles. The primer sequences used for RT-qPCR were as follows: MMP-2, forward 5'-GGATGATGCCTTTGCTCG and reverse 5'-GGAGTCCGTCCTTACCGT (12); 18sRNA, forward 5'-CTTAGT TGGTGGAGCGATTTG-3' and reverse 5'-GCTGAACGCCACTTGTCC-3' (13). The melting curves were assessed and the comparative $2^{-\Delta \Delta C \mathrm{q}}$ method was used to normalize the relative expression levels of the products generated by each set of primers (14).

Scratch wound healing assay. A scratch wound healing assay was used to assess the migratory ability of the U2OS osteosarcoma cells. U2OS cells were cultured in 6-well plates ( $1 \times 10^{6}$ cells/well; Corning Incorporated, Corning, NY, USA) with DMEM supplemented with $10 \%$ FBS. A pipette tip was used to make straight scratches of the same width in the monolayer of U2OS cells on the surface of each well. U2OS cells were treated as follows: Control, physiological saline; TNF- $\alpha, 100 \mathrm{ng} / \mathrm{ml}$ for $24 \mathrm{~h}$; TNF- $\alpha+\operatorname{ampelopsin,~} 50 \mu \mathrm{M}$ 
ampelopsin for $2 \mathrm{~h}$ prior to TNF- $\alpha(100 \mathrm{ng} / \mathrm{ml})$ incubation for $24 \mathrm{~h}$; ampelopsin, $50 \mu \mathrm{M}$ treatment for $2 \mathrm{~h}$ prior to physiological saline of equal volume for $24 \mathrm{~h}$. Images were captured to measure the wound healing under the Olympus IX71 microscope (Olympus Corporation, Tokyo, Japan) (10).

Transwell assay. A Transwell assay was used to assess the effect of ampelopsin on the invasive ability of U2OS osteosarcoma cells. Briefly, U2OS cells $\left(2 \times 10^{5}\right.$ cells/well $)$ were cultured in modified Boyden chambers with $8-\mu \mathrm{m}$ pore filter inserts (Corning Incorporated). The upper chamber contained cells in DMEM supplemented with $1 \%$ FBS, while the lower chamber contained DMEM supplemented with 10\% FBS. Following re-suspension in the upper chamber, U2OS cells were treated as described above for the control, TNF- $\alpha$, TNF- $\alpha+$ ampelopsin and ampelopsin groups. The cells remaining on the upper surface were gently wiped away with a cotton swab and the cells on the lower surface were fixed with $95 \%$ ethanol for $30 \mathrm{~min}$ and stained with $0.1 \%$ hexamethylpararosaniline following methanol fixation (Sigma-Aldrich) at $37^{\circ} \mathrm{C}$ for $30 \mathrm{~min}$ (10). The number of cells on the lower surface of the membranes was quantified using the Olympus IX71 microscope.

Statistical analysis. All data in the present study were evaluated with SPSS predictive analytics software, version 18.0 (SPSS, Inc., Chicago, IL, USA). One-way analysis of variance was used to analyze the normally distributed data, while Mann-Whitney U test was used to analyze the non-parametric variables with post-hoc test used for multiple comparisons between groups. $\mathrm{P}<0.05$ was considered to indicate a statistically significant difference.

\section{Results}

TNF- $\alpha$ upregulates MMP-2 expression at the protein and $m R N A$ levels. In a previous study, MMP-2 was correlated with aggressive tumor progression and low survival rates (15). Thus, the present study investigated the effect of TNF- $\alpha$ on the expression levels of MMP-2 in osteosarcoma cells. U2OS cells were cultured in 6-well plates and randomly divided into 5 groups, which were treated with $1,10,50$ or $100 \mathrm{ng} / \mathrm{ml}$ TNF- $\alpha$ for $24 \mathrm{~h}$, while treatment with physiological saline of equal volume was used as the control group. As demonstrated in Fig. 1A, TNF- $\alpha$ increased MMP-2 protein expression levels in a concentration-dependent manner. A significant effect was observed at a concentration of $50 \mathrm{ng} / \mathrm{ml}$ compared with the control group $(\mathrm{P}=0.0021)$ and peak MMP-2 expression was reached at $100 \mathrm{ng} / \mathrm{ml} \mathrm{TNF}-\alpha$ treatment (Fig. 1B; $\mathrm{P}=0.0017$ ). The results indicated that TNF- $\alpha$ may induce the migration of U2OS cells via the increased expression levels of MMP-2.

Additionally, the same TNF- $\alpha$ stimulations were performed and RT-qPCR was used to examine the mRNA levels of MMP-2. As demonstrated in Fig. 1C, following TNF- $\alpha$ treatment, the relative expression of MMP-2 mRNA was increased in a concentration-dependent manner. The MMP-2 mRNA expression level was significantly increased compared with the control group following stimulation with 50 and $100 \mathrm{ng} / \mathrm{ml}$ TNF- $\alpha(\mathrm{P}<0.00001)$.

Similar changes to MMP-2 protein and mRNA levels were observed, and thus, the data suggested that TNF- $\alpha$ induces
MMP-2 production in a concentration-dependent manner at the protein and mRNA levels.

TNF- $\alpha$ increases the phosphorylation of p38MAPK, with the effect abolished by ampelopsin. The current study aimed to elucidate the mechanism by which TNF- $\alpha$ induced the expression of MMP-2. In previous studies, the p38MAPK pathway was demonstrated to be an important regulator of MMP-2 following stimulation with a variety of cytokines in multiple cell types (16-19). TNF- $\alpha$ was previously reported regulate a number of biological functions via the activation of the p38MAPK pathway (20-22). Therefore, it was speculated that TNF- $\alpha$ may stimulate the expression of MMP-2 via the phosphorylation of p38MAPK. Following stimulation with TNF- $\alpha(100 \mathrm{ng} / \mathrm{ml})$ for 5, 15, 30, 60 and $120 \mathrm{~min}$, the proteins were extracted from U2OS cells. As demonstrated in Fig. 2A, the relative expression of phospho-p38 was significantly upregulated, compared with the control group, after $15 \mathrm{~min}$ stimulation $(\mathrm{P}=0.0014)$. Maximal activity was observed at $30 \mathrm{~min}$ of stimulation $(\mathrm{P}=0.0011)$, which gradually decreased after 60 and $120 \mathrm{~min}$ of stimulation $(\mathrm{P}=0.0018$ and $\mathrm{P}=0.0237$, respectively). Additionally, $50 \mu \mathrm{M}$ ampelopsin was cultured with U2OS cells for $2 \mathrm{~h}$ prior to TNF- $\alpha$ stimulation $(100 \mathrm{ng} / \mathrm{ml})$ for 5, 15, 30, 60 and $120 \mathrm{~min}$. As demonstrated in Fig. 2B, ampelopsin markedly inhibited the enhancement of p38 phosphorylation that was induced by TNF- $\alpha$ stimulation, and no significant differences in the levels of phospho-p38 were observed compared with the control group $(\mathrm{P}>0.05)$. These results demonstrated that TNF- $\alpha$ increased phosphorylation of p38MAPK, and that ampelopsin abolished the effect.

TNF- $\alpha$-induced expression of MMP-2 is mediated by the p38MAPK pathway and suppressed by ampelopsin. In order to further understand the importance of the p38MAPK pathway the upregulation of MMP-2 expression levels by TNF- $\alpha$, SB203580 (10 mmol/l), a specific inhibitor of p38, was used to pre-treat $\mathrm{U} 2 \mathrm{OS}$ cells for $2 \mathrm{~h}$ prior to TNF- $\alpha$ treatment for a further $24 \mathrm{~h}$. As presented in Fig. 3A and B, pre-treatment with SB203580 inhibited the TNF- $\alpha$-induced production of MMP-2, compared with the TNF- $\alpha$ only treatment group, at the protein $(\mathrm{P}=0.0191)$ and mRNA $(\mathrm{P}<0.00001)$ level, which strongly suggested that TNF- $\alpha$ increases MMP-2 production via the p38MAPK signaling pathway.

Additionally, ampelopsin was used to investigate whether it inhibits the effects of TNF- $\alpha$. U2OS cells were pretreated with various concentrations of ampelopsin $(5,10$ and $50 \mu \mathrm{M})$ for $2 \mathrm{~h}$ before TNF- $\alpha(100 \mathrm{ng} / \mathrm{ml})$ was added to the cells for a further $24 \mathrm{~h}$. As demonstrated in Fig. 3C and D, the enhanced MMP-2 expression level induced by TNF- $\alpha$ was gradually reduced with increasing ampelopsin concentrations. At $50 \mu \mathrm{M}$ ampelopsin, the expression of MMP-2 mRNA and protein was significantly reduced compared with the TNF- $\alpha$ group $(\mathrm{P}<0.00001$ and $\mathrm{P}=0.0072$, respectively). The results confirmed the importance of the p38MAPK pathway and the inhibitory effect of ampelopsin on TNF- $\alpha$-stimulated MMP-2 production.

TNF- $\alpha$ induces the migration and invasion of osteosarcoma cells. Wound healing and Transwell assays were used to assess 
A

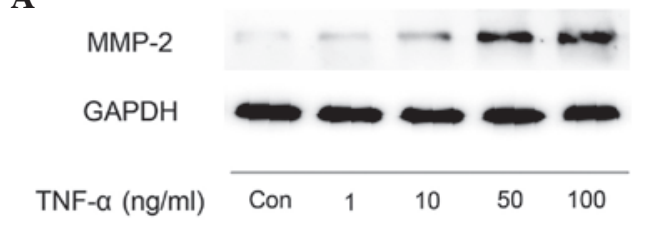

B

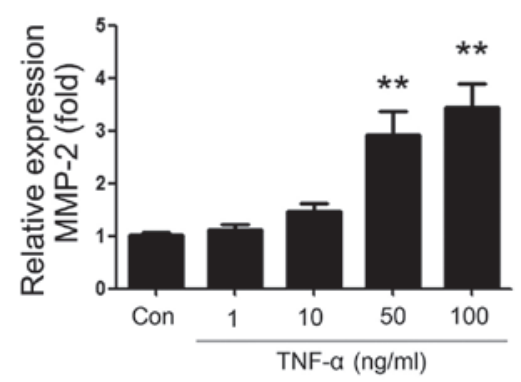

C

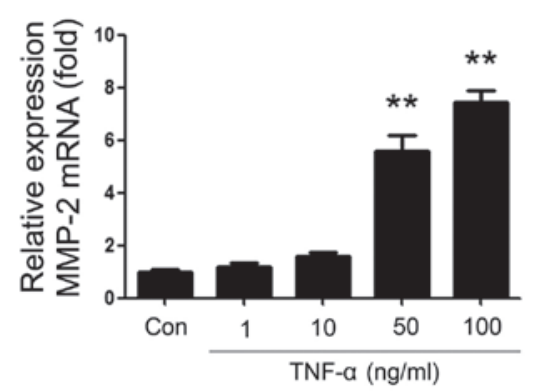

Figure 1. Increased expression of MMP-2 following TNF- $\alpha$ treatment. U2OS osteosarcoma cells were treated with $0,1,10,50$ or $100 \mathrm{ng} / \mathrm{ml}$ TNF- $\alpha$ for $24 \mathrm{~h}$, with the same volume of physiological saline used as the control group. (A) Western blotting was used to observe the changes of MMP-2 protein expression. (B) Quantification of western blot. (C) Reverse transcription-quantitative polymerase chain reaction was used to detect the mRNA expression level of MMP-2. ${ }^{* *} \mathrm{P}<0.01$ vs. the control group. Data are presented as the mean \pm standard error from three independent experiments in duplicate. TNF- $\alpha$, tumor necrosis factor- $\alpha$; MMP-2, matrix metalloproteinase-2; Con, control.

the effects of TNF- $\alpha$ on the migration and invasion of U2OS osteosarcoma cells, respectively. U2OS cells were cultured with $100 \mathrm{ng} / \mathrm{ml} \mathrm{TNF}-\alpha$ for $24 \mathrm{~h}$ in the TNF- $\alpha$ group, or physiological saline of equal volume was used in the control group. As presented in Fig. 4A, the wound healing assay demonstrated that TNF- $\alpha$ significantly enhanced the healing of the scratch wound compared with the control group $(\mathrm{P}<0.00001)$. The results indicated that TNF- $\alpha$ promotes the migration of U2OS cells. Additionally, as presented in Fig. 4B, the Transwell assay also demonstrated that treatment with TNF- $\alpha$ significantly increased the invasion cells compared with the control group $(\mathrm{P}=0.0087)$.

Ampelopsin suppresses TNF- $\alpha$-induced increases to osteosarcoma cell migration and invasion. Subsequently, to further clarify the effect of ampelopsin on the migration and invasion of osteosarcoma cells, U2OS cells were pretreated with $50 \mu \mathrm{M}$ ampelopsin prior to TNF- $\alpha$ stimulation. As demonstrated in Fig. 4A, the wound healing assay demonstrated that ampelopsin significantly inhibited the effect of TNF- $\alpha$ on wound healing areas compared with the TNF- $\alpha$ group $(\mathrm{P}=0.0032)$. As presented in Fig. 4B, the Transwell assay also demonstrated that pretreatment with ampelopsin significantly decreased the invasion of U2OS cells compared with the TNF- $\alpha$ group ( $\mathrm{P}=0.0069)$. These results indicated that ampelopsin suppresses the migration and invasion of osteosarcoma cells that is promoted by TNF- $\alpha$. The current study also investigated the effects of ampelopsin on the osteosarcoma cell migration and invasion when used alone, without TNF- $\alpha$ stimulation. The results presented in Fig. 4 demonstrated that ampelopsin treatment alone also had the ability to suppress U2OS cells migration compared with the control group $(\mathrm{P}=0.0251)$ or the TNF- $\alpha$ group $(\mathrm{P}<0.0000)$, and invasion compared with the control group $(\mathrm{P}=0.0376)$ or the TNF- $\alpha$ group $(\mathrm{P}<0.0000)$.

\section{Discussion}

Cancer metastasis is a complex biological process requiring multiple steps, including degradation of the ECM, activation of cell adhesion, migration and angiogenesis. The interactions between cells, cytokines, proteinases and the ECM that result in cell migration and tumor invasion are not fully clarified, however, TNF- $\alpha$ has been demonstrated to be important in inflammatory reactions, angiogenesis, cell proliferation and apoptosis via the regulation of various signaling pathways, including the phosphorylation of MAPKs $(23,24)$. TNF- $\alpha$ has been demonstrated to promote tumor angiogenesis, invasion and metastasis via upregulating the expression of angiogenic factors (25) and stimulating multiple cytokines and chemokines that accelerate the mobilization of tumor cells and their colonization to other tissues (26). Previous clinical reports have observed that the TNF- $\alpha$ concentration in serum was increased in patients with various types of cancer, including chronic lymphocytic leukemia (27), ovarian (28) and prostate (29) cancer. Simultaneously, chemotherapy significantly decreased the serum TNF- $\alpha$ concentration $(28,29)$. The ability of TNF- $\alpha$ to promote tumor progression has also been confirmed in animal models. Additional pathways associated with TNF- $\alpha$ upregulation of tumor growth include the vascular endothelial growth factor (VEGF) (25), hepatocyte growth factor (30), epithelial-mesenchymal transition (31), macrophage migration-inhibitory factor, chemoattractant protein-1 (24) and MMP (32) pathways. However, TNF- $\alpha$ was also reported to promote cancer cell death and exhibit an anti-oncogenic effect on certain tumors (33). Thus, the present study aimed to clarify the specific effects of TNF- $\alpha$ on the metastasis of osteosarcoma.

The human osteosarcoma U2OS cell line, which was initially derived from a moderately differentiated sarcoma of a 15-year-old female in 1964, has been widely used in biomedical research. The U2OS cell line has the lowest level of chromosomal numerical variations compared with other osteosarcoma cell lines. In addition, according to previous reports, only $2 \%$ of $\mathrm{U} 2 \mathrm{OS}$ cells have multipolar mitoses, which is similar to normal control fibroblasts (34). Thus, in the present study, the U2OS cell line was selected to represent osteosarcoma in vitro. The results confirmed that TNF- $\alpha$ significantly induced the migration and invasion of U2OS osteosarcoma cells. This result was in accordance with an investigation by Mori et al (35), which also demonstrated that TNF- $\alpha$ was required for the tumorigenesis of $\mathrm{AX}$ osteosarcoma cells. It is suggested that although TNF- $\alpha$ exerts a cytotoxic effect 
$\mathbf{A}$
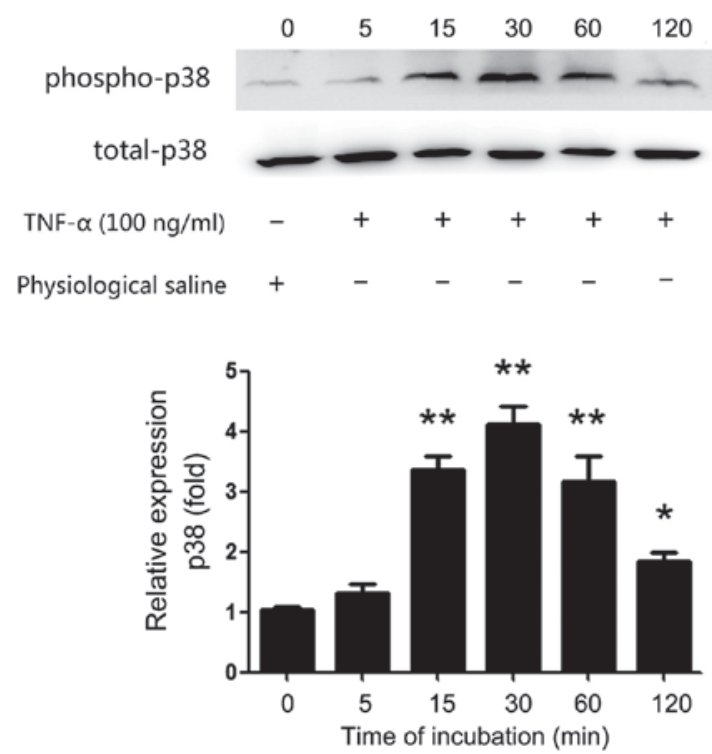

B
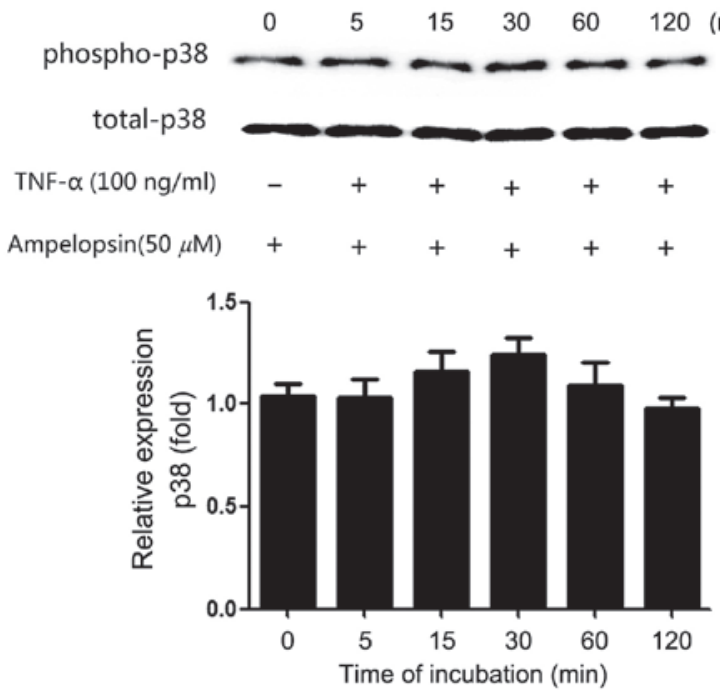

Figure 2. Phosphorylation of p38MAPK increased following TNF- $\alpha$ treatment, while ampelopsin abolished the effect. (A) U2OS osteosarcoma cells were treated with TNF- $\alpha(100 \mathrm{ng} / \mathrm{ml})$ for 5, 15, 30, 60 and $120 \mathrm{~min}$, with the same volume of physiological saline used as the control group. Western blot assay was performed to observe the change of phospho-p38MAPK protein expression. (B) Ampelopsin $(50 \mu \mathrm{M})$ was cultured with U2OS cells for $2 \mathrm{~h}$ prior to TNF- $\alpha(100 \mathrm{ng} / \mathrm{ml})$ addition to the supernatant for 5,15 , 30,60 or $120 \mathrm{~min}$, with the same volume of physiological saline used as the control group. Western blot was performed to measure the change to phospho-p38MAPK protein expression. ${ }^{*} \mathrm{P}<0.05$ and ${ }^{* *} \mathrm{P}<0.01$ vs. the control group. Data are presented as the mean \pm the standard error from three independent experiments in duplicate. Phospho, phosphorylated; p38MAPK, p38 mitogen-activated protein kinase; TNF- $\alpha$, tumor necrosis factor- $\alpha$.

on osteosarcoma, osteosarcoma cells may be resistant to the cytotoxicity.

The mechanisms of osteosarcoma metastasis are complex, involving multiple signaling pathways and various physiological changes. MMP-2 is an important member of the MMP super-family, the members of which act by digesting ECM molecules and promoting the invasion and metastasis of various types of cancer. The present study addressed one aspect of the multiple interactions of $\mathrm{TNF}-\alpha$ during tumorigenesis
A

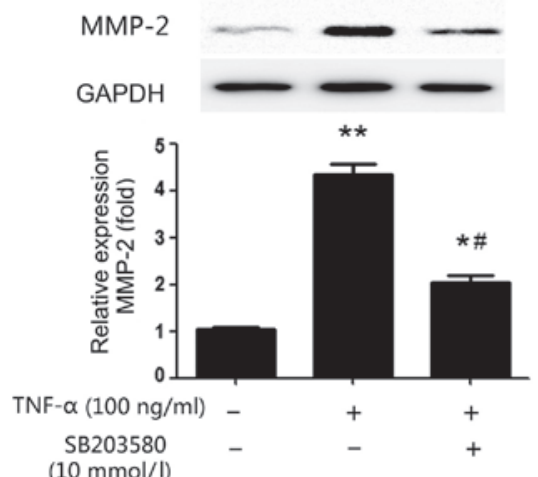

B
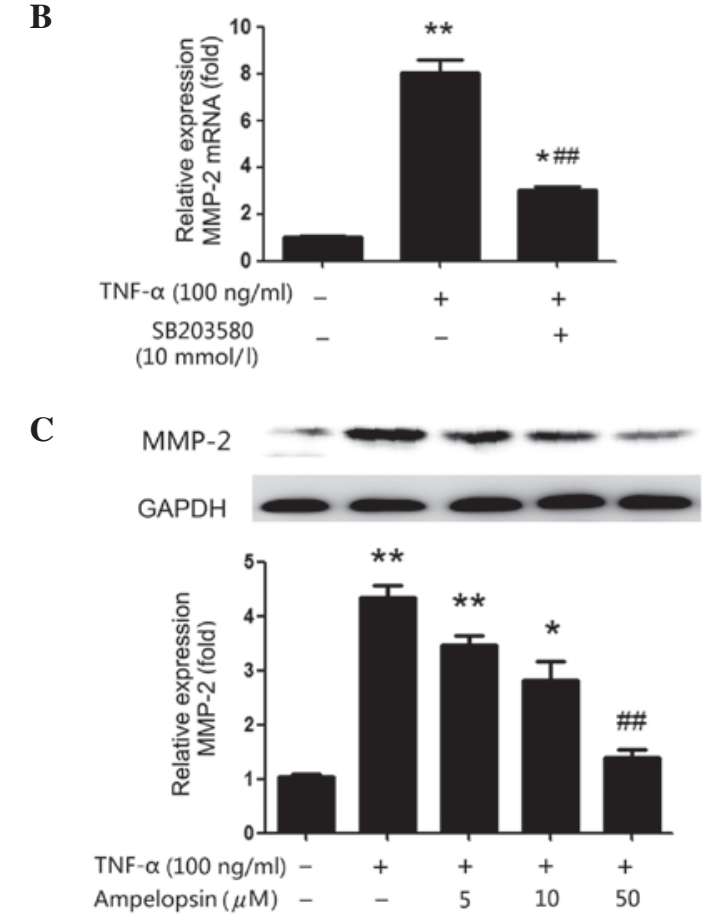

D

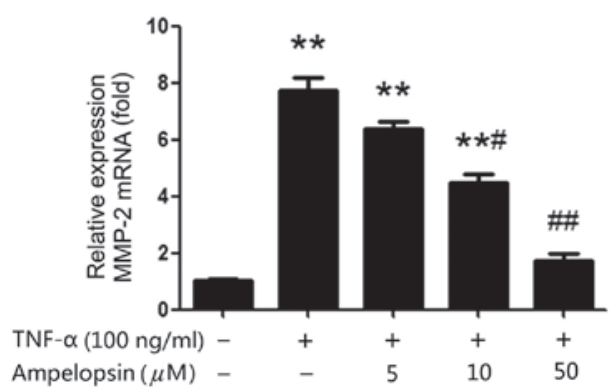

Figure 3. TNF- $\alpha$ induced the expression of MMP-2, which was mediated by the p38MAPK pathway, while ampelopsin suppressed the effect. SB203580 $(10 \mathrm{mmol} / \mathrm{l})$ was used to pre-treat U2OS cells for $2 \mathrm{~h}$ prior to TNF- $\alpha$ treatment for another $24 \mathrm{~h}$, the same volume of physiological saline was used as the control group. (A) Western blot and (B) RT-qPCR demonstrated that SB203580 significantly reversed the effect of TNF- $\alpha$ on MMP-2 expression. $\mathrm{U} 2 \mathrm{OS}$ cells were pre-treated with 5,10 or $50 \mu \mathrm{M}$ ampelopsin for $2 \mathrm{~h}$ prior to TNF- $\alpha(10 \mathrm{ng} / \mathrm{ml})$ addition to the cells for a further $24 \mathrm{~h}$, the same volume of physiological saline was used as the control group. (C) Western blot and (D) RT-qPCR demonstrated that pre-treatment with ampelopsin concentration-dependently reversed the effect of TNF- $\alpha$ on MMP-2 expression. ${ }^{*} \mathrm{P}<0.05,{ }^{* * *} \mathrm{P}<0.01$ vs. the control group; ${ }^{\#} \mathrm{P}<0.05$ and ${ }^{\# /} \mathrm{P}<0.01$ vs. the TNF- $\alpha$ group. Data are presented as the mean \pm the standard error from three independent experiments in duplicate. TNF- $\alpha$, tumor necrosis factor- $\alpha$; MMP-2, matrix metalloproteinase-2; RT-qPCR, reverse transcription-quantitative polymerase chain reaction. 


\section{A}

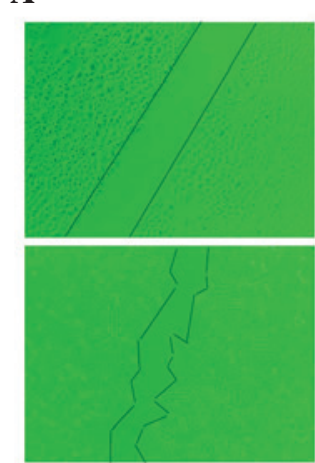

Control
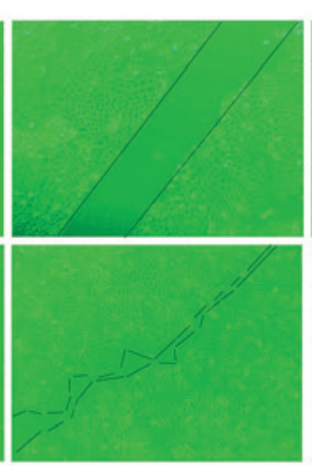

TNF- $\alpha$

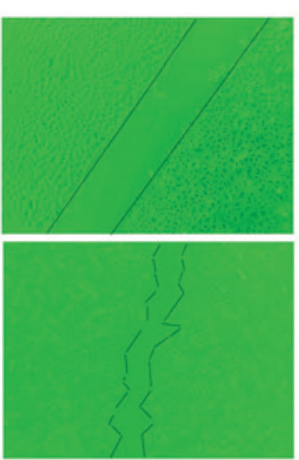

TNF- $\alpha+$ Ampelopsin
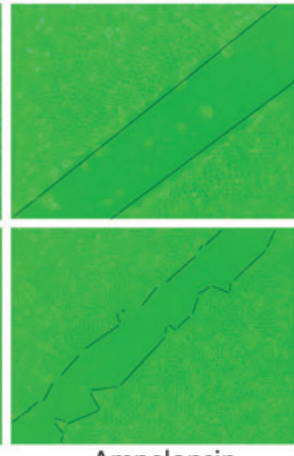

Ampelopsin

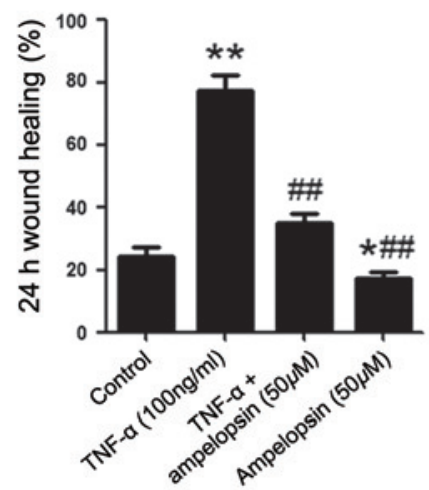

B

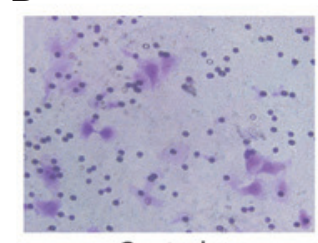

Control

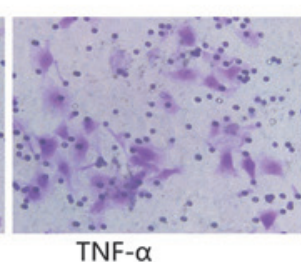

TNF- $\alpha$

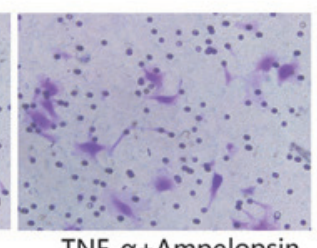

TNF- $\alpha+$ Ampelopsin

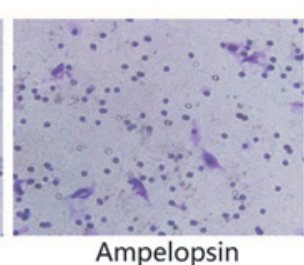

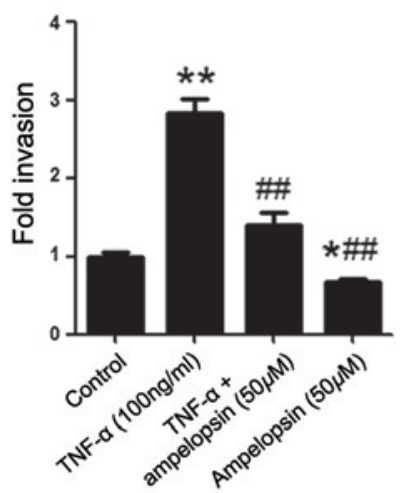

Figure 4. Ampelopsin inhibits TNF- $\alpha$-induced migration and invasion of U2OS osteosarcoma cells. U2OS osteosarcoma cells were treated with TNF- $\alpha$, TNF- $\alpha+$ ampelopsin (pre-treatment for $2 \mathrm{~h}$ ) or ampelopsin only for $24 \mathrm{~h}$, the same volume of physiological saline was used as the control group. (A) The effect of TNF- $\alpha$ and ampelopsin on the migration of U2OS osteosarcoma cells was assessed by a wound healing assay. (Top-panel) A pipette tip was used to make straight scratches of the same width in the monolayer of U2OS cells on the surface of each well. (Bottom panel) Following treatments images were captured to measure the wound healing. (B) The effect of TNF- $\alpha$ and ampelopsin on the invasion of U2OS osteosarcoma cells was assessed by a Transwell assay. $\mathrm{P}<0.05$ and ${ }^{* *} \mathrm{P}<0.01$ vs. the control group; ${ }^{\# \#} \mathrm{P}<0.01$ vs. TNF- $\alpha$ group. Data are presented as the mean \pm the standard error from three independent experiments in duplicate. TNF- $\alpha$, tumor necrosis factor- $\alpha$.

by determining the effects of TNF- $\alpha$ on an ECM remodeling enzyme, MMP-2. Previous reports have demonstrated that TNF- $\alpha$ activates the expression of MMP-2 in multiple cell types, including synovial fibroblasts, endothelial cells, dermal fibroblasts and corneal epithelial cells (36-38). The data of the present study confirmed the importance of TNF- $\alpha$ on the promotion of MMP-2 expression in U2OS osteosarcoma cells and provided further support for the theory that TNF- $\alpha$ increases MMP-2 activation via the phosphorylation of p38MAPK. In previous studies, the p38MAPK pathway was demonstrated to be an important regulator of MMP-2 following stimulation of several cell types with a variety of cytokines (16-19). The present study confirmed that p38 and MMP-2 proteins were highly expressed in U2OS osteosarcoma cells. Simultaneously, the results demonstrated that stimulation with TNF- $\alpha(100 \mathrm{ng} / \mathrm{ml})$ at different time points significantly upregulated the phosphorylation of p38MAPK and exhibited an abnormal time-dependent increase, with the peak activity observed at $30 \mathrm{~min}$. The application of SB203580 (10 mmol/l), a specific inhibitor of the p38 pathway, reduced the protein expression level of MMP-2 that was increased by TNF- $\alpha$, further confirming the theory that TNF- $\alpha$ promotes the expression of MMP-2 via the p38MAPK signaling pathway. Overall, these results suggested that TNF- $\alpha$ activates p38MAPK and increases MMP-2 expression through this pathway.
Ampelopsin is a type of flavonoid extracted from Ampelopsis grossedentata, a plant predominantly distributed in South China. The flavonoid is widely used to treat cold and tinea corporis, and has exhibited multiple biological functions in the processes of inflammation, oxidation, liver injury and hyperlipidemia. In previous studies, ampelopsin was demonstrated to possess anticancer properties in several types of malignant tumors. Ampelopsin has been reported to inhibit the proliferation of prostate cancer cells via the downregulation of B-cell lymphoma 2 expression, which is associated with cell apoptosis, and suppress migration and invasion via the downregulation of chemokine (C-X-C motif) receptor 4 expression (9). Ampelopsin was also observed to reduce breast carcinogenesis by inhibiting the mechanistic target of rapamycin signaling pathway (39). Ampelopsin also exhibits the ability to inhibit the secretion of VEGF and basic fibroblast growth factor, thus, inhibiting the development of hepatocellular carcinoma (40). In a previous study, it was confirmed that ampelopsin reduces the migration and invasion of ovarian cancer cells via inhibiting the epithelial-to-mesenchymal transition (10). Ampelopsin has demonstrated anti-carcinogenesis characteristics, however, direct evidence of ampelopsin involvement in osteosarcoma and the detailed molecular mechanisms have not been reported. The current study provided insight into the mechanisms by which ampelopsin regulates osteosarcoma cell migration and invasion. 
In the present study, pretreatment with ampelopsin for $2 \mathrm{~h}$ significantly inhibited the increases to MMP-2 expression stimulated by TNF- $\alpha$ in a concentration-dependent manner. Additionally, following pre-treatment with ampelopsin, the changes to the phosphorylation of p38 were no longer clear. As presented in Fig. 3A, it was demonstrated that ampelopsin significantly reduced the effect of TNF- $\alpha$ on the phosphorylation of p38. Therefore, in the current study, ampelopsin was demonstrated to be an inhibitor of the p38 signaling pathway, which mediated the expression of MMP-2. The results suggested that ampelopsin exerts an inhibitory effect on TNF- $\alpha$-induced MMP-2 production. The present study also investigated the effect of ampelopsin on TNF- $\alpha$-induced osteosarcoma cell migration and invasion; the results demonstrated that ampelopsin significantly reduced the effect of TNF- $\alpha$ on migration and invasion.

In summary, the present study demonstrated that ampelopsin inhibits TNF- $\alpha$-induced osteosarcoma cell migration and invasion, and the effect of ampelopsin was mediated by $\mathrm{p} 38 \mathrm{MAPK} / \mathrm{MMP}-2$ signaling. According to the results of the present study, the invasive properties of osteosarcoma cells may be reduced by ampelopsin via the inhibition of TNF- $\alpha /$ p38MAPK/MMP-2 signaling, and further in vivo studies should be performed in the future to confirm these findings.

\section{Acknowledgements}

The present study was supported by the Science Foundation of Shandong Province (no. ZR2014HP005).

\section{References}

1. Mirabello L, Troisi RJ and Savage SA: Osteosarcoma incidence and survival rates from 1973 to 2004: Data from the Surveillance, Epidemiology, and End Results Program. Cancer 115: 1531-1543, 2009.

2. Wu PK, Chen WM, Chen CF, Lee OK, Haung CK and Chen TH: Primary osteogenic sarcoma with pulmonary metastasis: Clinical results and prognostic factors in 91 patients. Jpn J Clin Oncol 39: 514-522, 2009.

3. Han YP, Tuan TL, Wu H, Hughes M and Garner WL: TNF-alpha stimulates activation of pro-MMP2 in human skin through NF-(kappa)B mediated induction of MT1-MMP. J Cell Sci 114: 131-139, 2001

4. Séguin CA, Pilliar RM, Madri JA and Kandel RA: TNF-alpha induces MMP2 gelatinase activity and MT1-MMP expression in an in vitro model of nucleus pulposus tissue degeneration. Spine 33: 356-365, 2008

5. Qi S, Xin Y, Guo Y, Diao Y, Kou X, Luo L and Yin Z: Ampelopsin reduces endotoxic inflammation via repressing ROS-mediated activation of $\mathrm{PI} 3 \mathrm{~K} / \mathrm{Akt} / \mathrm{NF}-\kappa \mathrm{B}$ signaling pathways. Int Immunopharmacol 12: 278-287, 2012.

6. Zhou WM, He RR, Ye JT, Zhang N and Liu DY: Synthesis and biological evaluation of new 5-fluorouracil-substituted ampelopsin derivatives. Molecules 15: 2114-2123, 2010.

7. Murakami T, Miyakoshi M, Araho D, Mizutani K, Kambara T, Ikeda $\mathrm{T}$, Chou WH, Inukai M, Takenaka $\mathrm{A}$ and Igarashi K: Hepatoprotective activity of tocha, the stems and leaves of Ampelopsis grossedentata, and ampelopsin. Biofactors 21: 175-178, 2004

8. Sayama K, Lin S, Zheng G and Oguni I: Effects of green tea on growth, food utilization and lipid metabolism in mice. In Vivo 14: 481-484, 2000.

9. Ni F, Gong Y, Li L, Abdolmaleky HM and Zhou JR: Flavonoid ampelopsin inhibits the growth and metastasis of prostate cancer in vitro and in mice. PLoS One 7: 38802, 2012.

10. Liu T, Liu P, Ding F, Yu N, Li S, Wang S, Zhang X, Sun X, Chen Y, Wang F et al: Ampelopsin reduces the migration and invasion of ovarian cancer cells via inhibition of epithelial-to-mesenchymal transition. Oncol Rep 33: 861-867, 2015.
11. Zhou Y, Liang X, Chang H, Shu F, Wu Y, Zhang T, Fu Y, Zhang Q, Zhu JD and Mi M: Ampelopsin-induced autophagy protects breast cancer cells from apoptosis through Akt-mTOR pathway via endoplasmic reticulum stress. Cancer Sci 105: 1279-1287, 2014

12. Tsai TT, Ho NY, Lin YT, Lai PL, Fu TS, Niu CC, Chen LH, Chen WJ and Pang JH: Advanced glycation end products in degenerative nucleus pulposus with diabetes. J Orthop Res 32: 238-244, 2014.

13. Ren P, Sun D, Xin D, Ma W, Chen P, Gao H, Zhang S and Gong M: Serum amyloid A promotes osteosarcoma invasion via upregulating $\alpha v \beta 3$ integrin. Mol Med Rep 10: 3106-3112, 2014.

14. Livak KJ and Schmittgen TD: Analysis of relative gene expression data using real-time quantitative PCR and the 2(-Delta Delta C(T)) Method. Methods 25: 402-408, 2001.

15. Bjørnland K, Flatmark K, Pettersen S, Aaasen AO, Fodstad O, Maelandsmo GM: Matrix metalloproteinases participate in osteosarcoma invasion. J Surg Res 127: 151-156, 2005.

16. Cheng YC, Kuo WW, Wu HC, Lai TY, Wu CH, Hwang JM, Wang WH, Tsai FJ, Yang JJ, Huang CY and Chu CH: ZAK induces MMP-2 activity via JNK/p38 signals and reduces MMP-9 activity by increasing TIMP-1/2 expression in H9c2 cardiomyoblast cells. Mol Cell Biochem 325: 69-77, 2009.

17. Zhong J, Gencay MM, Bubendorf L, Burgess JK, Parson H, Robinson BW, Tamm M, Black JL and Roth M: ERK1/2 and p38 MAP kinase control MMP-2, MT1-MMP, and TIMP action and affect cell migration: A comparison between mesothelioma and mesothelial cells. J Cell Physiol 207: 540-552, 2006.

18. Schram K, De Girolamo S, Madani S, Munoz D, Thong F and Sweeney G: Leptin regulates MMP-2, TIMP-1 and collagen synthesis via p38 MAPK in HL-1 murine cardiomyocytes. Cell Mol Biol Lett 15: 551-563, 2010.

19. Pan F, Ma S, Cao W, Liu H, Chen F, Chen X and Shi R: SDF-1a upregulation of MMP-2 is mediated by 38 MAPK signaling in pancreatic cancer cell lines. Mol Biol Rep 40: 4139-4146, 2013.

20. Li YP, Chen Y, John J, Moylan J, Jin B, Mann DL and Reid MB TNF-alpha acts via p38 MAPK to stimulate expression of the ubiquitin ligase atrogin1/MAFbx in skeletal muscle. FASEB J 19: 362-370, 2005

21. Stjernberg-Salmela S, Ranki A, Karenko L, Siitonen S, Mustonen H, Puolakkainen P, Sarna S, Pettersson T and Repo H: Low TNF-induced NF-kappaB and p38 phosphorylation levels in leucocytes in tumour necrosis factor receptor-associated periodic syndrome. Rheumatology (Oxford) 49: 382-390, 2010.

22. Bibikova E, Youn MY, Danilova N, Ono-Uruga Y, Konto-Ghiorghi Y, Ochoa R, Narla A, Glader B, Lin S and Sakamoto KM: TNF-mediated inflammation represses GATA1 and activates p38 MAP kinase in RPS19-deficient hematopoietic progenitors. Blood 124: 3791-3798, 2014.

23. Wajant $\mathrm{H}$ : The role of TNF in cancer. Results Probl Cell Differ 49: 1-15, 2009.

24. Wang $X$ and Lin Y: Tumor necrosis factor and cancer, buddies or foes? Acta Pharmacol Sin 29: 1275-1288, 2008.

25. Nabors LB, Suswam E, Huang Y, Yang X, Johnson MJ and King PH: Tumor necrosis factor alpha induces angiogenic factor up-regulation in malignant glioma cells: A role for RNA stabilization and HuR. Cancer Res 63: 4181-4187, 2003.

26. Kulbe H, Thompson R, Wilson JL, Robinson S, Hagemann T, Fatah R, Gould D, Ayhan A and Balkwill F: The inflammatory cytokine tumor necrosis factor-alpha generates an autocrine tumor-promoting network in epithelial ovarian cancer cells. Cancer Res 67: 585-592, 2007.

27. Ferrajoli A, Keating MJ, Manshouri T, Giles FJ, Dey A, Estrov Z, Koller CA, Kurzrock R, Thomas DA, Faderl S et al: The clinical significance of tumor necrosis factor-alpha plasma level in patients having chronic lymphocytic leukemia. Blood 100: 1215-1219, 2002.

28. Szlosarek PW, Grimshaw MJ, Kulbe H, Wilson JL, Wilbanks GD, Burke F and Balkwill FR: Expression and regulation of tumor necrosis factor alpha in normal and malignant ovarian epithelium. Mol Cancer Ther 5: 382-390, 2006.

29. Michalaki V, Syrigos K, Charles P and Waxman J: Serum levels of IL-6 and TNF-alpha correlate with clinicopathological features and patient survival in patients with prostate cancer. $\mathrm{Br}$ J Cancer 90: 2312-2316, 2004.

30. Tomita Y, Yang X, Ishida Y, Nemoto-Sasaki Y, Kondo T, Oda M, Watanabe G, Chaldakov GN, Fujii C and Mukaida N: Spontaneous regression of lung metastasis in the absence of tumor necrosis factor receptor p55. Int J Cancer 112: 927-933, 2004. 
31. Bates RC and Mercurio AM: Tumor necrosis factor-alpha stimulates the epithelial-to-mesenchymal transition of human colonic organoids. Mol Biol Cell 14: 1790-1800, 2003.

32. Hagemann T, Robinson SC, Schulz M, Trumper L, Balkwill FR and Binder C: Enhanced invasiveness of breast cancer cell lines upon co-cultivation with macrophages is due to TNF-alpha dependent up-regulation of matrix metalloproteases. Carcinogenesis 25: $1543-1549,2004$.

33. Villeneuve J, Tremblay $P$ and Vallières L: Tumor necrosis factor reduces brain tumor growth by enhancing macrophage recruitment and microcyst formation. Cancer Res 65: 3928-3936, 2005.

34. Niforou KM, Anagnostopoulos AK, Vougas K, Kittas C, Gorgoulis VG and Tsangaris GT: The proteome profile of the human osteosarcoma U2OS cell line. Cancer Genomics Proteomics 5: 63-78, 2008.

35. Mori T, Sato Y, Miyamoto K, Kobayashi T, Shimizu T, Kanagawa H, Katsuyama E, Fujie A, Hao W, Tando T, et al: TNFa promotes osteosarcoma progression by maintaining tumor cells in an undifferentiated state. Oncogene 33: 4236-4341, 2014.
36. Cooney R, Iocono J, Maish G, Smith JS and Ehrlich P: Tumor necrosis factor mediates impaired wound healing in chronic abdominal sepsis. J Trauma 42: 415-420, 1997.

37. Kitzis V, Engrav LH and Quinn LS: Transient exposure to tumor necrosis factor-alpha inhibits collagen accumulation by cultured hypertrophic scar fibroblasts. J Surg Res 87: 134-141, 1999.

38. Yang YN, Wang F, Zhou W, Wu ZQ and Xing YQ: TNF- $\alpha$ stimulates MMP-2 and MMP-9 activities in human corneal epithelial cells via the activation of FAK/ERK signaling. Ophthalmic Res 48: 165-170, 2012.

39. Chang H, Peng X, Bai Q, Zhou Y, Yu X, Zhang Q, Zhu J and Mi M: Ampelopsin suppresses breast carcinogenesis by inhibiting the mTOR signalling pathway. Carcinogenesis 35 : 1847-1854, 2014

40. Luo GQ, Zeng S and Liu DY: Inhibitory effects of ampelopsin on angiogenesis. Zhong Yao Cai 29: 146-150, 2006 (In Chinese). 